Research Article

\title{
Ozo Title: An Indigenous Institution In Traditional Religion That Upholds Patriarchy In Igbo Land South-Eastern Nigeria
}

\author{
Madukasi Francis Chuks. \\ Chukwuemeka Odumegwu Ojukwu University, Department of Religion \& Society. Igbariam Campus, \\ Anambra State, Nigeria. PMB 6059 General Post Office Awka. Anambra State, Nigeria.
}

\begin{abstract}
In Igbo land, the institution of $O z o$ title has underpinnings of male chauvinism and often used by men to remind those who appear to be very forward of their subordinate place in the society. Among the Igbo people, the $O z o$ title is an indigenous institution that is regarded as a central aspect of African indigenous religious practice through which they engage questions about the meaning for life. Through an ethnographic study conducted in recent years, I propose to explore the origin of the $O z o$ title and the symbolic significance of this indigenous sacred institution with specific reference to its religious, cultural, political, ethical and social significance, a method by which the indigenous communities keeps in constant religious communication with their deities and ancestors. However, I propose to not only examine the various ways in which $O z o$ title as a sacred institution has been used by their initiates to mediate religious beliefs and practices in African religion, but to specifically focus on its members as agents or ambassadors of different communities. Through an evaluation of significant Igbo religious practices involving $O z o$ title as a sacred institution performed by initiated men only which upholds patriarchy, I wish to suggest that the $O z o$ title as a sacred institution has two significant and related functions. The first one is that it enables the initiates to bridge the gap between the visible and unseen world of the ancestors and thus making possible an Igbo understanding of those forces that are believed to control the destinies of man. Secondly, $\mathrm{Ozo}$ title as a sacred institution of the Igbo is believed to uphold and sustain the Igbo religious system, and a complex of traditional religious rituals which uphold the privileges of those men who have been initiated into the ancestral cult. This paper point to particular understandings of $O z o$ title as integral to African religion, and proposes to illustrate this through an examination of Traditional Igbo Religion through the mediation of $O z o$ title as a sacred institution as part of the broader socio-sacral order.
\end{abstract}

Keywords: Aguleri, Brotherhood, Institution, Identity, Ozo, Patriarchy, Sacred, Rituals.

Introduction

The first question that comes to mind here is: who are the Igbo people? It would be very imperative to answer this very important question by giving a very brief historical analogy of the Igbo. One school of thought traces the origin of the Igbo people to that of the Jews who were believed to have migrated from Egypt (Idigo, 2001:25), no wonder Ikeanyibe (2001:30) describes the Igbo as the "resilient Nigerian Hebrews", who were "prevented from living legally, and prevented from surviving illegally" (Ojukwu, 1998:76). Buttressing this further, Enobabor Idahosa, a Bini, attests that "the Igbo man has come to earn my respect because of his tenacity to survive. He seems to convert each setback into strength immediately. Thus Igbos are like mysterious animals who feed as they are being shot: Anu ana agba egbe ona ata nni" (Ikeanyibe, 2001:31). According to Idigo, (1990:3) the word Igbo, is assumed to be a corruption of the name Hebrew. He argues that when the Hebrews left Egypt after four hundred years of servitude they crossed the river Jordan and wandered about in the Arabian Desert, for forty years. Some of them who did not reach the promise land found their way to Africa south of the River Nile and then into Nigeria (Idigo, 1990:3). The settlers at the confluence of the Niger and the Benue were a branch called Igala (Idigo, 1990:3). Ikeanyibe (1999:10) affirms that the words Igbo, Ibo, Ebo, $H E E B O$ are said to be a corruption of the name, Hebrew. As D. J Wiseman pointed out through the mouth of Ikeanyibe (1999:10) "the word Hebrew in Jewish language meant wanderer, or a people with no secure place in society" making them to be a tribal race destined to be "one people - one destiny" (Arkin, 1989:xi).

\section{Aguleri the Ancestral Home of the Igbo People}

However, when the Hebrew migrated from Egypt, they crossed the River Jordan and wandered around the Arabian Desert for about forty years. Some of them who could not reach the Promised Land, found their way into an area located at the south of the River Nile. The area later came to be known as Africa (Ikeanyibe, 1999:11). Okorie (1986:8) argues that "many other exiles from Nabatea province later joined them. They all settled together. Therefore, the first settlers were those from Judea province called Shechenigbo who are now being known as the Igbos, while those from Nabatea province, called the Efikdonaelis, are known as the Efiks". From that position, some moved southwards until they settled at the banks of Anambra River in the present Aguleri town in Anambra State of Nigeria in the West African sub-region (Eyisi, 2010:9), living their "original native town of the Igbos 
- Shechenigbo" (Okorie, 1986:9). Ikeanyibe (2000:7) opines that "the Igbos posses character, cultural, religious and various other identities which suggest that they have a peculiar relationship with the Hebrews world-wide". Ikeanyibe (1999:13) again argues that "if the similarities in culture, vocabularies and social institutions are the only yardstick to determine Igbo-Hebrew ancestry, the Igbo man may have a slippery ground upon which to continue his case". Ezeanya (1994:7) asserts that one important customs of the Igbo people of Nigeria in connection with the birth of a child is the naming ceremony. He affirms that for the Igbo people, as for the Hebrews, a name is not just a personal label for the sake of identity, it means much more (Ezeanya, 1994:7). Alford (1988:2) argues that "in some societies individuals receive their given names at birth and use these same names throughout their lives; while in other societies, individuals traditionally change their names at important points in their lives. And, finally, in some societies personal names are freely used in social interaction, while in other societies, personal names are regarded as intimate and private, and they must be kept secret”. Basden (1966:31) affirms that their language also bears several interesting parallels with the Hebrew.

According to John Bright (1981:165) "the fact that the traditional genealogy (Gen, 29:16 - 30:24; 35:16 - 20), while tracing the descent of all the tribes to the ancestor Jacob, has some of them [Gad, Asher, Dan, Naphtali] born not to Jacob's wives, Leah and Rachel, but to the two slave women, Zilpah and Bilhah, might lead one to suppose that inequalities were felt to exist". In fact, biblically the man Gad was the seventh Son of Jacob whom the almighty God renamed Israel. Gad was born to Zilpah, Leah's maid servant in the ancient city of Paddan - Aram [Northern Mesopotamia]. In 1749 BC, Gad was about forty years old when he and his entire house hold moved to Egypt along with his father, Jacob in $1728 \mathrm{BC}$, (Gen, 46:6-7). Before settling there, finally $\mathrm{Gad}$ had accompanied his brothers in two business trips to Egypt to get grain from Joseph who was the then prime minister of that land (Gen, 42:15). When their father moved to Egypt, all his family including Gad settled in the city of Goshen, where the Israelites lived for 430 years (Gen,45:10; 47:27; Ex 12:40). It is from this city of Goshen that Eri the fifth son of Gad, the great ancestor of the Igbos migrated to the interior part of what was later known as Africa (Eyisi, 2010:2). Eri and his entourage continued their migration southward until they finally settled at a place known to us today as Aguleri the ancestral home of the Igbo around 1303 B. C at the confluence of two rivers $E z u$ and Omambala - a tributary of the great River Niger (Eyisi, 2010:3). No wonder Aguleri has been described as the cradle of Igbo civilization because Eri the progenitor of Igbo race leaved there (Isichei, 1980:2)

Eyisi argues further that in Aguleri today, there is a place called Agbanabo-Ezu-na-Omambala [the confluence of the rivers, Ezu and Omambala, which form the Anambra River]. Here it is believed, Eri landed with his entourage before moving to settle in Obu-Gad, Aguleri. The Obu-Gad [that is Gad's memorial palace] is apparently visible and this remains a tourism site in Aguleri town of Anambra state till date
(2013:3). Igwah et al (2014:1) argues that this place is very paramount because "it was at this point that Eri had a divine revelation that they had reached their ordained place of settlement". Onwuejeogwu (1981:22) affirms that it is "from this point each settlement pursued its own separate existence and development, owing allegiance to Aguleri, where the collective ancestral temple of Eri still stands to this day". To ascertain the authenticity and significance of this site to the tradition, culture and hegemony of the Igbo people, Idigo (2001:42) asserts that "this is why before any Nri traditional ruler is installed, the king is led to Aguleri where he performs sacrifices to the sacred temple of Obuga before being given the sceptre of authority or Ududu Eze by the Igwe of Aguleri'". This depict that Aguleri people have a strong belief in the existence of one God, the creator of all things whom they call Chi-Ukwu, the Supreme Being, but ancestor worship is also practiced where the people offer sacrifices to their dead fathers (Idigo, 1990:60) where the King is believed to serve as an earthly representative between God and people, and this demonstrated convincingly that the concept of God was indigenous to the Igbo religious traditions (Metuh, 1981:7), which promises concrete blessings and protection (Isichei, 1980:4). Uchendu (1965:101) affirms that "the number of Igbo deities, spirits, and oracles is enormous and their anthropomorphous character is well recognized. He argues that "Igbo attitude towards the gods is not of fear but of friendship, a friendship that lasts as long as the reciprocal obligations are kept" (Uchendu, 1965:101).

\section{A Brief History of Aguleri [Igbo] Religion and Connection}

According to Idigo, Aguleri is a very large town situated at the bank of the river Anambra called Omanbala by the indigenes and corruptly nick named Anambra by the European Settlers (Idigo, 1990:3). He argues that Aguleri town is about 32 kilometers by the shortest land route to Onitsha and crossed by the line $6.53^{\circ}$ east longitudes and $6.22^{\circ}$ north latitude. The land is apparently low lying. During the rainy season the Anambra river, floods its banks to the extent or degree of so many kilometers depositing alluvial soil resulting in the great fertility of the soil (Idigo, 1990:1). Idigo (1955:2) asserts that "Aguleri people are basically farmers. Their traditional way of life was so eminently good and satisfactory that in recent times they have often been reluctant to abandon it by moving into the modern sector of the Nigerian economy". Nonetheless, since the beginning of this century, when Europeans began to penetrate, radical and constructive education is seriously pursued and this actually bring in development of small-scale industries, trading and manufacture (Idigo, 1990:1).

\section{Origin and Migration}

Strictly speaking, no one actually knows when Aguleri was incepted as a town but the history of Aguleri may have dated back to the early part of civilization and modernity in Nigeria (Idigo, 1990:3). Since there were no written records, the dates of events, origin and migration of Aguleri people depended heavily on time-honoured legends, oral tradition, recent 
archaeological discoveries and excavations where - "a site was excavated in Aguleri and radio carbon dates showed that it had been continuously inhabited for about 5000 years. There was no spectacular findings but it revealed ancient pottery, human bones and tools of stone', (Omoregie, 1989:16). The origin of Aguleri people would be linked to the migration of Igbo race to this present Nigeria as a nation who is among the "Hebrew patriarchs from Mesopotamia to their new homeland in Palestine (Bright, 1981:23). Bright (1981:73) again argues that "it is true that the position taken above, which is one that is widely held today, has been vigorously contested in recent years by certain scholars who maintain that the patriarchal narratives are more or less imaginative literary creations of a much later date [the early monarchy, or even the exilic period] with no appreciable stream of oral tradition behind them, and without real historiographical intention or historical worth",

\section{Settlement}

A wanderer and a warrior called Eri, the founder of Igbo race (Idigo, 2001:72) was among the migrants. He was believed to have moved and settled temporarily with his followers, in an area near the confluence of the Niger and Benue Rivers. From there Eri moved to the Anambra valley and quickly settled near the bank of the River Omanbala [corruptly called Anambra by the Europeans] at a place known as Eri-Aka near Odanduli stream, which is presently today located between Ivite and Igboezunu Aguleri respectively. Over time, Eri went out on war raids and captured many men and women and his settlement began to grow exceedingly (Idigo, 1990:3). Idigo (1990:4) again affirms that "Eri was married to Nono who bore for him six sons namely Agulu, Menri [Nri], Onogo [Igbariam], Nteje, Nsugbe, Amanuke and a daughter called Adamgbo. Having only one daughter, Eri refused to give her out in marriage but housed her to bear children for him'. According to Idigo (1990:3-4) again "after the death of Eri, his off springs grew in number. To avoid over-crowding and to prevent a situation where all of them could fall prey in an attack which was then the order of the day, the son's dispersed to different places of abode today. The children of Agulu, the first son, remained in their grandfather's [Eri] abode, and together with Adamgbo's children, evolved the town, Aguleri. To Agulu's name was appended to his father's name Eri, making Agulu-Eri. This is because he doesn't want his father's name to be forgotten', Menri's children settled at Nri and later expanded to Umunri communities. Onogu's off springs took their residence at Igbariam while Ntemeje's children lived at Nteje, and later dispersed into some parts of Asaba and Anam (Idigo, 1990:3).

Nonetheless, through the institutions of royal ordination and ceremonial rituals and spirit manifestation, Aguleri reasserted her authority over other Igbo's in diaspora to "represent the headship of Igbo race" (Nnamah, 2002:9). Nnamah (2002:9) again asserts that "it is also very vital to mention here that Aguleri is strategically located at the point of origin of Igbo land from where Igbo land spread further into the hinterland". He argues that the significance is that Aguleri as a town, represent the boundary of Igbo land from where Igbo land stretched eastwards to the rest of its heartland and equally, it is important to note that every major cultural expression in Igbo land in terms of arts, artifacts, symbolism, and names of different types and so on are found in Aguleri (Nnamah, 2002:9). This cultural expression is only typical of the cradle and for a boundary community it makes a stronger claim to originality (Nnamah, 2002:9). More so, till date, Aguleri has retained the original Igbo form of writing that is compared with the Egyptian hieroglyphics is another good point to claim the originality for boundary community and all these marks Aguleri identity (Nnamah, 2002:9) which McAdams (1988:18) refers to as a well "structured self-image"'. Neuman (1980:12) argues that an ancient town like Aguleri is "the birth place, ancestral home, and a historical centre of culture. Other areas, important as some have now become, are nevertheless derivative from tradition'. Insofar as some of the areas deriving their art music from the great tradition of Aguleri became, themselves, "great centers for the dissemination of musical culture, though geographically distant from its original place and surrounded by different local traditions, other areas remained little centres of the great tradition", (Capwell, 1993:96).

\section{Origin of Ozo Title}

We should not forget the fact that it was Eri the progenitor of the Igbos who introduced the republican and aristocratic institution of Ozo tiltle known as Odoloma Eri. This sacred institution of $O z o$ title taking as a system of government strategy in Igbo land started since the time of Eri - 'Ube Eri' (Idigo, 2001:103). In Aguleri Kingdom, the Odoloma Eri later metamorphosised into Ozo title society and its members act or sever as advisers and ambassadors to Eri who were mainly made up of spiritualized fathers (Idigo, 2001:110-119). But according to Onwuejeogwu (1981:168 \& 67) this group later was transformed into a secret society, which has a highly disguised language that is understood only by its members and such secret language was developed and used before indoctrination and for domination, "so that the head of the ritual groups could send messages backwards and forwards". It is on this positions that Nabofa (1994:19) connected/interpreted this ethical values to the notion that wisdom belongs to the elders and describes the $O z o$ titled men as "the voice of the elders which invariably is the voice of wisdom", that "reminds an initiate of his responsibilities and obligations to his fellow members"' (Nabofa, 1994:14). Pupil (1927) describes such initiates as "those who tread the path of wisdom and also find peace".

It is important to note that women are not admitted into society because it is all men's affair. Supposedly, Matory (1993:61) admits that women cannot be trusted due to the fact that they can divulge the secret information and may betray the town on important matters because of the secrecy involved. Shepherd (1987:153) argues that "women are necessary as the source of life, as well as potentially dangerous in their power to withdraw it'. No wonder the proverb of the Gikuyu of Kenya says: "women, like the weather, are unpredictable", and "women have no secure 
gourds, but only leaking, upside down ones" - you can't trust women with secrets" (Mbiti, 1991:66-67).

No wonder Idigo (2001:118) comments that the Ozo titled men are spiritually developed and some could have magical powers and they are next in command to the King. The status quo for the qualification of an Ozo title is that one must have entered the stage of gerontocracy. But either in gerontocracy or republican system of administration in Igbo land, they are at the helm of affairs in the council of elders called Ndi-chie (Idigo, 2001:118). Idigo (2001:118) again argues that were it not for the introduction of Western civilization, the members of Ozo title society could have been the chief priest as well as the medical consultants of today. In reviewing this assertion, I must say regrettably that for Idigo to say that the members of Ozo title society could have been the chief priest as well as the medical consultants of today if not for the introduction of Western civilization, because from the tune of his argument the members of the $O z o$ society were alienated from the practice of traditional religion which is tenuous; and his oblique acceptance of obsolete detribalized Africa is unacceptable. Also, Idigo should not deny the fact that these are the people that know the entire repertoire and who performs the rituals meticously as decreed by the God(s) and ancestors so that it can retain its original ritual connotations in order to avoid sacrilege. That is why they are referred to as the spiritualized fathers in Igbo cosmology.

\section{Dressing Code}

As a point of emphasis, it is very paramount to mention here that the dress code of the members of the Ozo title holders is the Isi-agu dress and the Igbo native red cap and where necessary with the eagle feathers and beads portraying royalty, hegemony, aristocracy and leadership in Igbo cosmology. No wonder Idigo (1990:65) comments that "the titled men form a society of high rank having a special uniform of dress or cloth, arm or leg rings, iron staff, hat and ivory trumpet and no commoner could mimic this style with impunity". Bosah (1973:36) cited in Hahn-Waanders (1990:88) asserts that the symbology of "the red caps worn by other chiefs was introduced by Obi Okosi [1901-1931] in order to differentiate the members of the native courts from other title holders and from ordinary citizens". He affirms that "these red caps are called okpu ododo. Ododo is a Bini word and it means red. Later on, these red caps were worn by the $O z o$ members all over Igbo land" (Hahn-Waanders, 1990:89). No wonder why traditional red cap popularly called Okpu Ododo in Igbo language serves "as the most distinctive symbols of the political elite to identity membership in a royal family or a connection to the aristocracy" Perani \& Wolff (1991:135). Perani \& Wolff (1999:125) again affirms that "the visual brilliance and textual complexity is enriched by scintillating surface, sparkling and shining in a kaleidoscope of color and light in the appearance of the mounted ruler under an impressive twirling state umbrella". McMullen (1987:217) asserts that the colour combination of the Isi-agu material portrays the symbolism and "the benevolence of the cosmic order and of his own role in mediating between it and the human hierarchy". Kaplan (2000:117-118) argues that insofar as the King wears the Isi-agu cloth and "seats on his throne, he is awe-inspiring. He alone possesses the royal coral-bead regalia - the crown, the staff, and the royal coral bead shirt and strip wrapper combined with different colous which have symbolic meanings. He is a living proof of the cogency of Kingship. Nonetheless, he has the ability to control the beneficent and destructive forces of the earth",

However, the colours of the Isi-agu regalia may be combined in significant ways, but their meaning/symbolism is situational and can never be read automatically; one cannot write dictionaries of symbolism in African art (MacGaffey, 2000:233). In fact, in Igbo cosmology, the Isi-agu attire worn by some designated people especially the prestige in society express "value of identity and incorporation" (Smith, 1987a: 28). In terms of leadership context, the communicative significance and symbolism of Isi-agu attire could act as "tracers of rank" and bolster the visual hierarchy cannot be over emphasized (Schneider, 1987:412). Kaplan (2004:190) argues that in Igbo cosmology Isi-agu attire is one the "the clothing the king chooses to wear each day is traditional and symbolic with meanings. It is a statement of occasion, intent, mood, power and all have meanings and evoke memory', Through, the symbolism it utilizes and the cultural ethos it invokes, however, the Isi-agu attire retains the power to influence the spiritual state of its wearer and to play a role in the socio-religious consciousness of the person by whom or for whom it is worn. This is why Susanne Langers (1942:195) describes object based symbols like the Isi-agu attire as an "unconsummated symbol, a significant form without conventional significance". This is why Hall (1928:136) argues that "the regalia must be worn correctly and must not be worn profanely", because it is classified as a "robe of honor" or "coronation cloth" (Perani \& Wolff, 1999:124 \& 166). This royal ceremonial regalia creates also a symbolic distinction between what Vansina (1978:185) axiomatically refers to as "the elite from the commoner". Bayero (1981) attested that "to wear these gowns is to be different from other people. When you see them, you know this person is of the royal family".

\section{Ozo Title and Church Position}

Mention has to be made that title-taking like the Ozo initiation has nothing to do with the liturgy of the Church but it is of such classified significance to Igbo land in our contemporary society today, and indeed to several other parts of Nigeria. Title-taking is a time honoured custom among the Igbos and it is so revered that most people even the wealthy Christians want to be initiated into the society. Traditionally, it is often believed to be connected with some pagan religious ceremonies by the Christian converts. No wonder Ekwueme (1974:13) laments that "early missionaries tagged all indigenous forms of arts as the work of the devil, especially as almost invariably those associated with some religious or quasi-religious ceremonies... The amount of damage done materially and psychologically to the culture of the Igbo by these misguided zealots may probably never be fully 
assessed". In recent years the titled men in some places have maintained that these religious ceremonies are not essential to the title-taking. According to Francis Arinze:

When therefore, Christians wish to take title in a town, the parish priest and the local Catholic community must first make an exhaustive inquiry into the title in question. If it is found that the title of itself, contradicts faith or morals, then no Catholic can take it, no matter under what conditions. But if it is found that the title us a purely social affair at the taking of which some pagan religious ceremonies were performed, then the title society must agree to abolish these religious ceremonies for all candidates who take title. An agreement is then signed between the title society and the Catholic Community of the town. Only after such a signed agreement may a catholic proceed to take title. The aim of the agreement is not to Christianize any title. The aim is to remove the pagan religious ceremonies from them so that the titles remain purely social or economic propositions (1973:53).

Buttressing this further, Idigo wrote that:

Christians of various dominations were prohibited by their churches from taking titles because the ceremonies in course of taking the titles are mingled with the pagan rites. It has not been easy for these Christians to forgo the time-honoured custom of title-taking which is regarded as being very advantageous in raising one's social status encouraging industry and serving as pension to the aged. In order to avoid participating directly or indirectly in the pagan worship connected with title taking and yet reap the benefits of taking titles, the Christians and the pagans came to agreement approved by the church hierarchy that the procedure of taking title should be the payment of money which substitutes the yams, the cooking of food and sacrificial ceremonies according to pagan rites (1990:66).

\section{The Problem with the Igbo People}

Nonetheless, due to the syndrome of what I can describe as 'Igbo Enwe Eze'-Igbo does not have a King or leader which Okafor (1994:116) argues that "the saying is a political philosophy derived from the proto-type political ideology characterized by egalitarian and republican features and its political system is complex and dynamic which is based on the segmentary lineage system where every man is a god in his house; every village an autonomous community'. HarneitSievers (1998:60) argues that this "theory is welcome in current popular and political debates about chieftaincy, as it seems to be able to prove the character of contemporary Igbo traditional rulers titles'. Isichei (2004:286) asserts that "historians and ethnographers have always applied the word king to a wide range of dignitaries located at different points along a range from priestlike ritual figures to powerful rulers". According to Isichei (2004:286) again "there is a proverb to that effect that the Igbo have no kings [Eze]. In some polities, including Asaba in the late nineteenth century, eze was a title multiplied deliberately, and held by many men as a safeguard against oppressive rule but it is now dying because of its ritual restrictions'. Buttressing this assertion, the symbolic interpretation of this proverb is that no one person rules any Igbo community and this made Francis Arinze to affirms that:

The Ibos are unique among the other peoples of Nigeria in the decentralization of political authority in Iboland in the past. While the Yorubas had their mighty Obas and Fulanis their powerful Emirs, the Ibos' greatest political organization was often the town, village-group, or commune. Only Onitsha and some Western Igbo towns had the Obi or Kings, but the influence of these rulers was limited practically to their own towns (1970:7).

\section{Stages and Significance of $O z o$ Title}

In Achebe's “Things Fall Apart”, the emissaries sent from Umuofia to mediate in the case of impending killing of Ikemefuna actually depict the real significant of these titled men in Igbo land. This is because an ordinary youth does not know the implications of prohibitions (Nso Ani) in Igbo cosmology. It is only the people that have attained the stage of gerontocracy status quo that knows it all as far tradition and customs are concerned. This gerontocracy status quo is part of the qualification that makes one an ancestor as it is believed in traditional religion. Ozo title taking in Igbo land is an elaborate and rigorous ritual affairs/exercises and it involves so many things that has to do with so many ritualistic endeavours as stipulated by Idigo (2001:101-110) and Onwuejeogwu (1981:82-95) respectively. It is very important to note here that in all of these Ozo initiation rites, the chief priest that is allowed to officiate in the whole ritual exercise is an Nri priest. This is because Menri\{Nri\}has an official responsibility for ensuring that the prospective members of Odoloma Eri meet the following criteria (Idigo, 2001:104107). Interpretatively, I can say tersely here that Nri has a special position in Igbo land as a ritual elder statesman in Igbo cosmology like the chosen one from the house Levite in the Bible. That is the reason why there is a deep ritual connection between Aguleri and Nri irrespective of the fact that Aguleri is the ancestral home of the Igbo race and the cradle of Igbo civilization.

However, it is imperative to say here that for one to be bestowed with an Ozo title interpretatively it "implies a hierarchy of privilege and dependency" (Roberts, 1993:65) because there are so many obligations attached to it. One thing we should be mindful of is the fact once a person is initiated into the brotherhood, politically "he becomes a member of the traditional ruling group. Thus he becomes a member of $\mathrm{Ndi}$ nze, one of the state councils, and he is regarded as a man of upright character and integrity (Onwuejeogwu, 1981:85 \& Idigo, 2001). Socially, the initiated person has the right to own, keep and use all Ozo paraphernalia - red cap, the white ankle threads, the double-headed spear, alo, the single-headed iron lance, nguegiliga, the ofo-ozo, the ozo bronze bell, he elephant tusk, okike and Oche-mgbo respectively. He can be called by any of his four names. He can have the shrine of Agbala, Anyanwu and Ebo (Onwuejeogwu, 1981:85 \& Idigo, 2001:109).

Interestingly, all these paraphernalia are ritualized, imbued with spiritual powers in order for them to radiate extra 
spiritual and angelic potency. Jean During (1993:561) asserts that such paraphernalia given to members of $O z o$ society as a sacred institution symbolizes "the image of both the heavens and the assemble circle of mystics". All these retain their religious aspects of its spiritual values as well as the social. The initiate of Ozo title is remarkably an important political personality both at his clan, lineage and state levels respectively while his conferment of $O z o$ title is ritually tied on his ability and pedigree to uphold and speak the truth, maintain equity and justice without fear or favour. He continues to enjoy his position while he is alive but if at any point in time he is found wanting in any of these, his council with the consent of Eze could strip him of his Ozo title (Onwuejeogwu, 1981:85). Economically, being a member of Ozo title means safeguarding oneself against poverty at old age this is because older title holders has a share in the yams and other food items given to subsequent title takers in settlement (Idigo, 2001:106). This is the reason why it is seen as a system of banking which serves as old age pension that encourages mutual assistance in the family and encourages industry (Idigo, 1990:65). In the aspect of spiritualism, an Ozo initiate in pursuit of spiritual excellence enhances his individual and general spiritual development in the brotherhood.

\section{Ozo Title and Patriarchy}

However, Ozo title taking is an intrinsic element of Igbo tradition and culture, and "it has gained immense popularity because of the representative qualities of its symbolic approach. Frankly speaking, the initiation of Ozo members into the secret brotherhood apparently becomes the heart beat of the Igbo communities, no wonder Hussein (1970) cited in Nanji (1994:54) affirms that such sacred institution represents what he refers to as "matter and desire" which its "rhythmic beat of life is very distinct and unbridgeable". Robert Nicholls (1988:198) argues that as a sacred institution, the initiates "have inherited a melo-rhythmic tradition of talking instruments. The principal instrument in this category, the idiophonous slit-drum, perhaps is best known as a traditional transmitting instrument of telegraphy'. More so, the $O z o$ title and its membership "represents more of a process than a product, based on this, it carries its own rules of etiquette", (De Jong, 2010:199) because the accessibility of the instrument to ordinary members of the community who are not initiates is highly restricted. Nonetheless, it is believed in Igbo cosmology that for the ordinary member of the community to attain that 'mystical glory' in order to be a member, it is only when the King and his cabinet members are partaking in its initiation rituals that some paraphernalia that are ritually imbued with some spiritual potency are handed over to them for their self spiritual upliftment. Through this form, the $O z o$ members dramatically swirl in a ritual dance to create what Fitzgerald et al (1995:57) refers to as "breeze of blessing" to infect the mystical experience on behalf of the entire community who are not initiates. Arguably, in the psychology and belief of the Igbo people, it is these mystical feelings, experiences and expressions that make Ozo initiation to be central to Igbo ritual life. This kind of experience of the "Numinous", in Rudolf Otto's observation, leads one to a kind of self-evaluation which evokes in him a feeling of selfabasement and dependence. The Holy also combines the attributes of that which causes a sense of awaresomeness, eeriness, daunting self-abasement and inadequacy with that of attractive and often irresistible magnetism (1973:5ff).

Daniel Pals (2009:109) argues that such sacred items or paraphernalia when used "substantively therefore designates the thing whose essential characteristic is sacredness"'. Bolaji Idowu argues that the "sacred informs and gives meaning to the common, and the common is for the sacred a means of self-expression" (1973:58). On this position, Derion \& Mauze (2010:6) posits that words like "sacred/secret/sensitive", would be used to describe object like the 'Iron spear or alo' because it "commands respect and therefore require special care or the observation of prohibitions; in all events". In a simple phrase, Derion \& Mauze (2010:6) again argues that such sacred object "propose to use the all-encompassing expression culturally sensitive object, which is less reminiscent of religion and emphasizes the native peoples' values and sensitivities effectively at the heart of the matter'. It is on this ground that David Brown (1975:43) affirms that "anything or any place could become sacred".

Maria-Gabriele Wosien (1992:10) argues that due to the theology and asceticism which add their share to the repression of spontaneous movement; eventually the membership becomes a taboo and is regarded as dangerous, underground or evil manifestation. The sacredness conferred on Ozo title members by the Igbo communities is partly positive and partly negative among the initiates, neo-phytes and "especially women and minors" (Nabofa, 1994:18). Ogundipe (2007:29 affirms that there are several places that women are forbidden to enter in view of the widespread fear of the contagious blood in them. John Durham (2001:2) argues that "on the one hand, it had to be kept separate from the profane; it should not be touched or looked at by profane persons; when not in use, it is hidden in special location, itself made sacred by association'. Femi Adedeji (2013:1) affirms that "it is a blend of the sacred and secular'. Doubleday (2006:124) posits that attributions of sacred symbolism may express androcentric ideas. Miriam Clavir (1996:100) argues that such items "commands respect and can give rise to prohibitions as to who may view, touch or use it'; because it is used during the ritual initiation for the titled men through their "Ozo dance" — dance for the titled men (Achebe, 1958:41).

It is through this practice that the initiates who are also the custodians of the tradition and customs of the community "pursue practices and ideals embedded within a tradition that has historically accorded women a subordinate status" (Mahmood, 2005:4-5), and confers male religious authority. In fact, in Igbo cosmology the institution of $O z o$ title "has overtones of male chauvinism and is often used by men to remind who appear to be very forward of their subordinate place in society" (Metuh, 1999:129). Elizabeth Isichei 
attributes it to "abhorrence of menstrual blood; a kind of role selection in which men are perpetual performers of an art, women are perpetual spectators; while many observers have seen it as a way of subordinating women" (1983:289).

\section{Ozo Title taking and Restrictions against Women and} Minors

In the tradition and culture of the Igbo people, the $O z o$ as a sacred institution is highly prized and as such in this patriarchal tradition there are restrictions put upon women, non initiates and the children insofar as they are prohibited from becoming members or initiates. Proverbially, this is the reason why Joy Lo-Bamijoko (1987:23) affirms that "in Afikpo area, women are still not allowed to see or listen to these instruments while they talk" and they are not allowed to touch or carry them. Bruce Lincoln (1989:89) posits that integration of such laws "is necessary for the smooth and harmonious functioning of society is regularly sought and accomplished through numerous overlapping systems and mechanisms - among them law, pedagogy, etiquette, aesthetics and ideology, particularly religious ideology". Reed \& Hufbauer (2005:135-136) argues that through the initiation into the $O z o$ society, the Igbo concepts of gender are articulated and the restrictions of women through such membership is tied to ritual and political authority. Thomas Beidelman (1993:41 \& 43) asserts that secrecy and the public acknowledgement of concealment create an etiquette that helps further the aims of those men who maintain the ritual and social hierarchy. Reed \& Hufbauer affirms that "such carefully delimited categories maintain political boundaries and create categories of legitimate and illegitimate knowledge" (2005:136). In other words, it is the initiates that are legitimate here, while the illegitimate includes men that are not initiated, women and minors. Against this background, participant 015 , Mr. James, a fifty six year old non-imitate explains that "women are not allowed not partake in such ritual initiation because it is believed to be the membership of brotherhood for the gods and ancestors".

From the above assertions from some of my participants, it has been observed that in Igbo custom and tradition, women are not allowed to partake in anything that concerns the Ozo title ritual because it is believed to be the initiation solely for men in Igbo communities who are the earthly representatives of the gods and ancestors. Equally significant is that not only women but also men that are not initiated and children. African feminist scholar, Amina Mama (1995:12) asserts that "such a view confers epistemic privilege on those who are disempowered and marginalized in our societies" and in this way women are enslaved by religious patriarchy. George Basden argues that although, sacred artifacts are said to "inspire fear, but practically it is the women and children who suffered intimidation" (1966:366). Participant 014, Mr. Peter, a forty five years old non-initiate affirms that "women are not allowed to participate in the ritual initiation of $\mathrm{Ozo}$ membership. It is an abomination for them to do so".

From the above assertion from my participant, it has been noticed that women generally are exempted from participating in anything that concerns the rituals of Ozo initiation and these rules tends to instigate dominance against them. Eric Ayisi asserts that "these rules have religious implications and people who overlook them feel a sense of guilt and seek ritual restoration" (1972:91). Likewise, Lo-Bamijoko argues that "the functions for which those... are used take place at night, in order that women may hear the... but not see either of them" and this makes women invisible (1987:23). Warren D'Azevedo (1994:345) writing from the context of Poro a secret society in Sierra Leone affirms that "the position of women remains subordinated to that of men, because Sande may be viewed as an instrument of male control of women in which the high-ranking leaders of Sande engage in an ancient conspiracy with their dominant male lineage-mates to sustain the principles of patrimony"'. Temple (1922) cited in Isichei (1983:289) writing from the context of Dodo secret society of Kagoma traditions affirms that the "initiates were told that the whole society was really a conspiracy to keep their women folk in subjection". Analytically, from the above, one would say that there is a deep connection between traditional religious practices and women domination particularly in the West African sub-region.

John Shepherd affirms that "male hegemony is essentially a visual hegemony". He argues that "the male desire to control women therefore parallels their desire to control the world, which implies that women themselves must be controlled and manipulated"' (1987:154). Reed \& Hufbauer argues that men link the dominance of male initiates of the $O z o$ "to the control of women's knowledge and behaviour, and describe it as an important means of dividing male and female responsibilities and priviledeges" (2005:136). Reed \& Hufbauer again goes further to states that members of sacred institution Ozo title are upheld as the custodians of its secrets and mysteries, whereas women, children, and uninitiated men are spectators who must nonetheless provide the necessary support. It is on this position that Pals (2009:109) explains that these profane persons, that is to say, "women and young men that are not yet initiated into the religious life are not allowed to touch or dance the music, they are only allowed to look at it from a distance and even this is only on rare occasions". James Frazar concludes that "in general, we may say that the prohibition of women and the effects supposed to follow an infraction of rule, are exactly the same whether the persons to whom the things belong are sacred or what we might call unclean or polluted (1922:190).

\section{Women's Blood as Threat to Ozo Title Initiation and Spiritual Potency}

From the above discussion from my participants, it has been observed that because of the nature of women being that they menstruate, they are not allowed to partake in the ritual initiation of the Ozo title taking. The reason is because it is believed in Igbo cosmology that their menstrual blood has that power to defile the spirit of that is behind the ritual process. This also signifies that women's blood is a powerful element that can render certain rituals useless in traditional belief 
system. It is on this position that: participant 014, Mr Peter, a forty five years old non-initiate affirms that "a woman who is her menstrual period cannot come nearer to the initiation ground not to think of becoming an initiate".

It is on this ground that Bruce Derr asserts that menstrual period "is a luminal state whereby the menstruating woman in preindustrial society symbolizes the dangers facing such societies" (1982:645). Jacob Olupona (1991) argues that almost all cultures throughout the world have elaborate beliefs and practices about menstruation; and African practices no doubt are part of this larger tradition. He affirms that in all African cultures, menstruation is associated with women's secret power - often expressed also in witchcraft as antithetical to men's secret power: one of the ways in which women exert force and power mystically in the universe and on men (Olupona, 1991:6). Participant 04, Chief Nwave, an eighty four year old initiate asserts that "it is not allowed or permitted for women to come closer where the initiation rituals are being performed in Igbo land. Women are regarded as not being clean; this means that they can defile the laws and spiritual potency that surrounds the initiation of $O z o$ members".

From the above assertion, it has been noticed that in Igbo religion, menstrual blood from women is regarded as a negative force that can render the efficacy of any ritual sacrifice powerless. Then, in relation to the initiation of members into $O z O$ society, the menstrual blood of women can equally do the same that is the more reason why women are not allowed to be part of anything that pertains to the $O z o$ title taking. Buttressing this further, Joseph Murphy observes that in religion like that of the Igbo, "the menstrual blood from women can disturb the physical and spiritual compounds that enable sacred..." (2012:78). Thomas Buckley (1993:134) writing in the context of the Indian law and belief system, argues that "a menstruating woman is highly polluting and will contaminate the family house and food supply if she comes into contact with either. Thus, in the old days, a special shelter for menstrual seclusion was built near the main house, and special food for a family's menstruating women was separately collected, stored, and prepared for consumption in this shelter". Participant 011, Chief Ndigwe, a eighty nine year old initiate comments that:

For emphasis, all cultures across the Igbo land do not allow women's participation in such sacred ritual like that of the $O z o$ title to avoid violating the guiding rules and regulations that constitutes the essence of the membership of the men's society. Women do menstruate, and a menstruating woman can defile the spiritual essence of the $O z o$ membership.

From the above assertion, it has been discovered that throughout Igbo land women are prohibited to be part of the $O z o$ initiation ritual for the fear of defilement. Teresa Velez suggests that one of the views advocated by promoters of such patriarchal religions would argue that "in order to protect them [women], not the... and it is believed that the spirit that inhabits the..., desirous of blood, may cause women to bleed to death" (2000:156). Women are afraid of it, and if one should see the activities forbidden to women she would no longer conceive (MacGaffey, 2000:238). Nabofa (1980:394) asserts that "this is one of the major reasons why women, especially those who are still of child-bearing age are often precluded from taking key positions in many religious activities". It is on this note that Metuh (1985:89) asserts that sacred initiations like the $O z o$ title taking "is surrounded by a set of prohibitions. Ordinary people may on the advice of a priest or diviner adopt and practice certain prohibitions and thus achieve a limited level of holiness. It would appear therefore, that prohibitions create or preserve the status of holiness [nso], while the breach of prohibition [nso], result in pollution or unholiness. Nso are therefore sacred prohibitions".

Buckley (1991:45) affirms that "traditionally, when a girl menstruates for the first time she undertakes a ten-day period of seclusion and ritual activity, an amplified version of the routine she'll follow during each of her periods until menopause". Molara Ogundipe (2007:29) asserts that "as the woman is sacred in endogenous thought, her body is also sacred. According to Michael Nabofa (1996:11) "the study of African thought forms and religious practices have revealed some beliefs and symbolic cultic practices associated with blood and its uses for positive and negative ends which have multivocal symbologies encoded, with varied meanings decoded from it. Ogundipe (2007:29) argues that "they can and are used as blessings, curses, and potions for power social, material and supernatural". She argues that women's menstruation is considered sacred and powerful, and that it is believed to have the power to interrupt, interfere with and cause to happen (Ogundipe, 2007:29). Such a thing is the "symbolic representation of the embodiment of womanhood" (Ozah, 2006:67). Olupona (1991:6) comments that "it could not be that the biological nature of women is sinful, but rather that blood, which is a symbol of life, has some potency, which can itself destroy. It may be that people like to put this potential threat/power at bay, to control, so to say, that which is highly charged with the sacred". Richard Leppert writing in the context of playing the family piano in England argues that "in this instance, the virginal, anthropomorphized as woman, is made by the violence imposed upon her. Music is posited as harmony, but harmony is produced by a beating. Aestheticized as music, women's very being is articulated as a product of a deferential masochism in response to sadistic revenge...Yet even in the privacy of the playing, such instruments' discursive boundaries must be preestablished" (1992:109).

\section{Ozo Title Taking and its Ritual Dance: Bolstering Patriarchy}

On the issue of how the $O z o$ members are being appointed in order to bolster patriarchy, there are stipulated steps according to the tradition and custom of the community one would follow and these falls under the theme social and ritual authority. On this, participant 013, Mr Paul, a fifty year old non-initiate asserts that "...the appointment/membership is through getting to the stage of gerontocracy and the members must be solely men". Participant 011 , Chief Ndigwe, a eighty 
nine year old initiate posits that "....the person selected by both ancestors and the deities will be a person of integrity and avid observant of the guiding rules of Ozo society"

From these observations, it has been shown that the Ozo membership cannot be approve by 'anyhow, anybody' without the approval of the deities, ancestors, the king, the members of existing Ndi-chie as this would constitute a violation of Igbo cosmology. This also sees the men in such position as privileged because it is believed that they are divinely selected and appointed. On this note, participant 018, Chief Arinze, an eight two year old initiate asserts that "...it is rigorous... because of certain rituals that are involved. ... it is only the titled men in the community or family that could be appointed or chosen". Participant 03, Chief Onyema, a fifty eight year old initiate affirms that "when the person is chosen, certain sacrifices would be performed in order to initiate the person into the brotherhood of Ozo society".

From the above, it is has been noticed that it is through the attainment of gerontocracy state and apart from the fact that divination process is involved to enable the wishes of the gods and ancestors to be known. It is after such sacrifices that the person would be initiated into the Ozo title society. Participant 013, Mr. Paul, a fifty year old non-initiate affirms that:

If women are allowed to partake in the ritual initiation of the Ozo title taking, it is believed that the deities and ancestors would not be happy. It is also believed that the goodwill messages we usually derive from the obligations surrounding the Ozo society might cease because its potency has been defiled.

From the above, it has been noticed that in Igbo worldview, it is not every man that is permitted to be members except the old men who must have attained certain status in order not to defile the spiritual capabilities of being a member. This situation is remarkable because in many other regions - parts of Europe and Sub-Saharan Africa for instance, sacred initiation is traditionally performed by men, not women (Doubleday, 2006:109). Insofar as it is not proper in Igbo tradition for women or minor to over step their boundaries or do the obvious in matters or roles strictly meant for males, nonetheless, all these put a check and balance on the type of rituals being performed by any categorized group, male or female (Ibekwe, 2013:143). Again, insofar as ritual, cultic and esoteric affairs usually involved in the sacredness of the $O z o$ initiation have male dominance and women are highly restricted from intruding or interfering in such situations, therefore, it would be seen that both culturally conceived notions and biological sex differentiation are at play in gender definition, which in turn influence ritual performance typology (Ibekwe, 2013:138). Buttressing this concept of the sacredness of the Uvie on the theme: instrument of social and ritual authority on why women are not allowed to partake in its ritual dance, participant 015 , Mr James, a fifty six year old non-initiate explains that:

Uvie dance would be compared to Sulugede dance in Igbo tradition, because it is believed to be a ritual dance for the gods and ancestors. This dance is believed to be a ritual dance for the gods and the ancestors in Igbo land and women are not allowed to partake in such ritual dance because it is believed to be for the spirits and ancestors.

From this, we can see that traditionally Igbo women are not allowed to participate in the ritual dance of the Uvie but in another way I can interpret it to mean a kind of male dominance which Ali Rattansi (1997:494) argues that the resultant reactionary consequences of this is what he describes as "the romantic culturalist chauvinism" which means that the initiates has formed a dominant club for themselves. Participant 01, Chief Nweke, an eighty two year old initiate says that "the Uvie is not meant for women at all. The Uvie music is very distinct and important for the $O z o$ initiates. It is the ritual dance for the Egbenobas - that is men of valor or the warriors of the community".

Basically, an Uvie dance practice from my own observation is seen as a traditional ritual dance meant only for initiated men. This is because it is assumed to be the dance for the gods. Ibekwe (2013:142) explains that there are significant areas where men have advantages over women in sacred music which includes ritual music, wrestling music, hunting music, war music, and initiation music and so on. Van Allen (1993:459) argues that "in traditional Igbo society, women did not have a political role equal to that of men. But they did have a role - or more accurately, a series of roles - despite the patrilineal organization of Igbo society. Their possibilities of participating in traditional politics must be examined in terms of both structures and values'. That is why Lester Monts (1989:220) asserts that musicianship in Uvie musical practices like other professions is divided along gender line.

However, the sacredness of the Uvie as a sacred sound offers an amazing field for the exploration of gender inequality and power becomes evident because according to Valji et al (2003:72) "modesty, submissiveness and fear of authority" would be attributed to the cause of this gender inequality and restrictions in many aspects which also includes music. Insofar as culture represents routine behaviour that carry's norms and values of a society, they are often not easily changed (Steady, 2005:326). Phil Okeke (2000:50) consistently argues that the tendency to regard gender discrimination inherent in cultural practices as being acceptable because it is the tradition. Saba Mahmood (2005:2) argues that it is under the pretence of tradition that women are enchained. Al-Bukhari (1928) cited in Mernissi (1991:49) writing from the Islamic point of view asserts that "those who entrust their affairs to women will never know prosperity', Leppert (1987:64) argues that "this attitude reached its climax in the early nineteenth century in the establishment of rigid distinctions between both peoples at all levels of interaction".

It is also noticeable in the same community where men and women play different roles in the areas of musical practices especially as it concerns instrument like the Uvie (Ibekwe, 2013:137). Strictly speaking, this religious structure of the Igbo in the context of Aguleri tradition, culture and hegemony 
as regards the sacredness of Uvie drum is apparently chauvinistic and a symbol of women's oppression which portrays "women as timeless victims of a ferocious patriarchal order" (Zeleza, 2005:213). Rattansi (1997:485) argues that "the feminization of the colonized male also of course occurred in the context of the masculinism of imperialism and the dominance of the male in the metropolitan order of things. It is therefore appropriate to turn to another recent contribution to post-colonialism literature in which many of these issues are particularly well highlighted'. On this, participant 09, Mrs. Nneka, a sixty six year old woman sacred specialist also asserts that "...there are women who are sacred specialists that are believed to be even more spiritually powerful than their male counterparts. ...As a woman sacred specialist, am advocating that women should be permitted to partake in the ritual dance".

From the above, it has been observed that irrespective of the fact that women are been marginalized in the area of the Uvie, there are other ways like in the area of spirituality, they still distinguished themselves and that makes their agitations very strong. On this position, John Brenkman (1987:231) argues that this notion of dominance is a "socially organized forms of exploitation, coercion, and nonreciprocity which structure the uses that one individual or group makes of another for the satisfaction of its own need'. Arguably, on the theme: Bolstering patriarchy and alienating gender on the position of male dominance why women are not allowed to partake in the Uvie ritual dance, participant 08, Mrs AveMaria, a fifty two year old lay Christian woman contests that "it is satanic and archaic. ...for those women that are involved in the worshipping of idols...it will be good if they should be allowed to partake in it. By not permitting such women they marginalize them in this area. ...it means it is gender biased". Again, participant 08, Mrs. AveMaria, a fifty two year old lay Christian woman again explains that "there is a kind of segregation and dominance against many of us that are married to those chiefs. In this $21^{\text {st }}$ century people still belief in fetish ideas and sacrifices. I see this ritual of a thing as a medium in which Satan/devil uses to operate".

Overall, from my observation here, in order to bolster traditional and institutional patriarchy through the sacred ordinance of the Uvie sacred sound and for the fact that women's blood can defile the spiritual potency of the Uvie drum therefore they are not allowed to touch it. Also, through the mediation of its ritual dance which the women are not allowed to participate in, all through the response to its sacred sound therefore, this upholds the Uvie and the traditional patriarchy in Igbo cosmology. Nonetheless, there is a kind of power dynamics where women are dominated and marginalized in everything that concerns the musical instrumentation of the Uvie. Even, there is a kind of contestations from some of the community women that such rule is gender biased, while some concludes that for the fact that women are side tracked in this area, there must be something hidden and fetish about the Uvie association especially in this modern era. All together, those voices are agitating that all the women should be initiated into the ritual instrumentation of the Uvie. It is on this position that Helene La Rue (1997:189) asserts that musical instruments like the Uvie can be makers of culture, as well as status; they can also imply the status of gender, while Stokes (1997:22) argues that playing of musical instruments like the Uvie not only define ranks and hierarchies but gender. In this form, the totality of the instrumentation of the Uvie and its ritual practices becomes "more assertive and emotionally indulgent", (Sugarman, 1989:202). David Brackett (2012:120) refers to this kind of gender struggle and inequality as "social/power dynamics".

\section{Conclusion}

Nonetheless, the Ozo title taking in Igbo land is perceived to be sacred and the title that is made sacrosanct by the Igbo communities in diaspora that is the reason why there are some many by-laws that guides and protects the $O z o$ as a sacred institution and these are the main reasons why women are not allowed to partake in its ritual initiation and this upholds the traditional patriarchy of the Igbo race. The brotherhood of Ozo members/initiates rely heavily on their oaths, obligations and articles of their faith during initiation because it is believed that through the mediation of its secrecy the community interacts with their deities in the socio-sacral order where the spirit invocation of their deities are constructed and activated, while spirit of their ancestors are managed.

\section{References}

[1] ADEDEJI, F. 2013. History of Nigerian Gospel Music. 13. Available From: nigeriangospelchurch.org/History of Nigerian Gospel Music.pdf. Accessed: 12 November 2013.

[2] AYISI, E. 1972. An Introduction To The Study of African Culture. Nairobi: East African Educational Publishers Ltd.

[3] ACHEBE, C. 1958. Things Fall Apart, London: Heinemann Educational Books.

[4] ARINZE, F. 1973. The Church And Nigerian Culture. Onitsha: Tabansi Press Ltd.

[5] ARKIN, M. 1989. One People - One Destiny: Some Explorations in Jewish Affairs. Hillcrest: Owen Burgess Publishers.

[6] ALFORD, R. D. 1988. Naming And Identity: A CrossCultural Study of Personal Naming

[7] Practices. New Haven, Connecticut: Hraf Press.

[8] BASDEN, G. T. 1966. Among The Ibos of Nigeria. London: Frank Cass \& Co. Ltd.

[9] 1966. Niger Ibos: A Description of The Primitive Life, Customs And Animistic

[10]Beliefs, etc, of The Igbo People of Nigeria. London: Frank Cass \& Co. Ltd.

[11]BAYERO, A. 1981. Personal Communication, Bichi, Kano State, Nigeria.

[12]BROWN, D. A. 1975. A Guide To Religions. Great Britain: SPCK.

[13]BRENKMAN, J. 1987. Culture And Domination. Ithaca 
Madukasi Francis Chuks / Ozo Title: An Indigenous Institution In Traditional Religion That Upholds Patriarchy In Igbo Land South-Eastern Nigeria

\& London: Cornell University Press.

[14]BRACKETT, D. 2012. Preaching Blues: Introduction: At The Cross-Roads. Black Music

[15] Research Journal, Vol. 32, No. 1. Spring 2012. 113-136. Available From: http://muse.jhu.edu/journals/black_music research_journal/v032/32.1.brackett.pdf.

Accessed: 11

January 2013.

[16]BUCKLEY, T. 1991. Doing Your Thinking cited in I Become Part of It: Sacred Dimensions in Native American Life (ed) D. M. Dooling \& Paul Jordan -Smith, New York: Harper Collins. 32-52.

[17] 1993. Menstruation And The Power of Yurok Women cited in Gender Cross-Cultural Perspective (Edited) by Caroline B. Brettell \& Carolyn F. Sargent (1993). New Jersey: Prentice-Hall Inc. 133-148.

[18] BEIDELMAN, T. O. 1993. The Paradox of Knowing and The Knowing of Paradox cited in Secrecy: African Art That Conceals And Reveals, (ed) by M. H. Nooter, New York: Museum for African Art. 41-47.

[19]BRIGHT, J. 1981. A History of Israel. London: SCM Press Ltd.

[20] CAPWELL, C. 1993. The Interpretation of History And The Foundation of Authority In The Visnupur Gharana cited in Ethnomusicology And Modern Music History (ed) by Stephen Blum, Philip V. Bohlman \& Daniel M. Neuman (1993), Urbana \& Chicago: University of IIIinois Press. 95-102.

[21] CLAVIR, M. 1996. ' Reflections On Changes In Museum And The Conservation of Collections From Indigenous Peoples', Journal of the American Institute for Conservation 35 (2): 99-107.

[22] D'AZEVEDO, W. L. 1994. Gola Womanhood And The Limits of Masculine Omnipotence cited in Religion In Africa: Experience And Expression (ed) by Thomas D. Blakely, Walter E. A. Van Beek, \& Dennis L. Thomson (1994), London: Heinemann. 343-362.

[23] DOUBLEDAY, V. 2006. The Frame Drum in the Middle East: Women, Musical Instruments, and Power, cited in Ethnomusicology A Contemporary Reader (ed) by Jennifer. C. Post, 2006, New York: Routledge.109-133.

[24] DURHAM, J. C. 2001. Durkheim on the Sacred. 1-3. Available From: www.bytrentsacred.co.uk/index.php/durkhei m-on-religion/Durkheim-on-the-sacred.

Accessed: 5 May 2013.

[25] DERION, B \& MAUZE, M. 2010. Sacred or Sensitive objects. 1-20.Available From: www.necep.net/ papers/05 -Derion-Mauze.pdf. Accessed:2 October 2012.

[26]DURING, J. 1993. Daf(f) and Dayera 1 cited in Encyclopaedia Iranica, (ed) by Ehsan Yarshater, vol. VI, fasc 6, Costa Mesa: Mazda Publishers. 560-562.

[27] DE JONG, N. 2010. The Tamba of CuraAsao: Historical Projections And The Ritual Map of Experience.Black Music Research Journal, Vol. 30, No. 2, Fall 2010, 197214.

Available From: http://muse.jhu.edu/journals/bmr/summary/ v030/30.2.de-jong.html.
Accessed: 2 March 2013.

[28]DERR, B. W. 1982. 'Implications of Menstruation as a Liminal State'. American Anthropology, New Series, Vol. 84, No. 3 (Sept 1982), 644-645. Available From:http:// www.jstor.org/stable/677341. Accessed: 28 October 2014.

[29]EKWUEME, L. 1974. African Music in Christian Liturgy: The Igbo Experiment. African Music. 5, no.3. (1973/1974); 12-33. Available From: www.jstor.org/stable/30249968. Accessed: 4 March 2014.

[30] EZEANYA, S. N.1994. A Handbook of Igbo Christian Names. Onitsha: Tabansi Press Ltd.

[31]EYISI, V.M.C. 2010 . Igbo History [With Bible References]. Onitsha: Chuvic Publishers.

[32]FRAZAR, J. 1922. The Golden Bough: A Study of Magic and Religion. London: Temple of Earth Publishing.

[33] HAHN-WAANDERS, H. 1990. Eze Institution In Igbo land: A Study of An Igbo Political System In Social Change. Nimo, Nigeria: Documentation Centre, Asele Institute.

[34] HARNEIT-SIEVERS, A. 1998. Igbo Traditional Ruler: Chieftaincy And The State In Southeastern Nigeria. Africa Spectrum, Vol. 33, No. 1 (1998), 57-79. Available From:http://www.jstor.org/stable/40174764. Accessed: 25 April 2014.

[35] HALL, M. P. 1928. The Secret Teaching of all Ages: An Encyclopedia Outline of Masonic, Hermetic, Qabbalistic and Rosicrucian Symbolical Philosophy. San Francisco: H. S. Crocker Company, Incorporated.

[36] IKEANYIBE, U. 1999. Biblical Evidences: Confirming the Hebrew Origin of Igbo People.

[37] Benin: Seed Sowers Publication.

[38]__ 2001. Agonies of Ndi-Igbo: A Chronicle of 150 Years of the Groanings of 40 Million People. Benin: Seed Sowers Publication.

[39]ISICHEI, E. 1980 Entirely for God: The life of Michael Iwene Tansi. Ibadan: Macmillan Nigeria Publishers Ltd.

[40]_1983. The History of Nigeria. London: Longman Group Limited.

[41]__2004. The Religious Traditions of Africa: A History. London: Praeger Publishers.

[42] IDIGO, F. C. 2001. Eri kingdom of An Igbo king From Israel. Lagos: X-Pose CommunicationsLtd.

[43] IDIGO, M. C. M. 1955. The History of Aguleri. Lagos, Yaba-Lagos: Privately Printed.

[44]__ 1990. Aguleri History And culture. Lagos: Bantam Press Ltd.

[45] IDOWU, E. B. 1973. African Traditional Religion: A Definition, London, SCM Press Ltd.

[46] IBEKWE, E. U. 2013. Gender Identity: A Force In Igbo Traditional Musical Practices. 137-144. Available From: www.ajol.info/index.php/cajtms/article/viewFile/76589/6 7038. Accessed: 21 January 2013.

[47] IGWAH, R; OKOYE, E; CHINWUBA, O; NNECHI, J; NNAMAH, P; CHIKWENZE, R; IKEM, E; EJIMOFOR, G \& CHIEZE, C. 2014. 'Aguleri Is the Ancestral Home of The Igbos, Not Nri'. Available From: 
Madukasi Francis Chuks / Ozo Title: An Indigenous Institution In Traditional Religion That Upholds Patriarchy In Igbo Land South-Eastern Nigeria

www.nairaland.com/1813782/aguleri-ancestral-home-

igbos-not. Accessed: 18 July 2014.

[48] KAPLAN, F. E. S. 2000. Some Thoughts On Ideology, Beliefs, And Sacred Kingship Among The Edo (Benin) People of Nigeria cited in African Spirituality: Forms, Meanings And Expressions (ed) by Jacob K. Olupona (2000), New York: The Crossroad Publishing Company. 114-151.

[49] 2004. Understanding Sacrifice and Sanctity In Benin Indigenous Religion, Nigeria: A Case Study cited in Beyond Primitivism: Indigenous Religious Traditions And Modernity (ed) by Jacob K. Olupona (2004), New York: Routledge.181-199.

[50] LINCOLN, B. 1989. Discourse and the Construction of Society: Comparative Studies of Myth, Ritual, and Classification. New York: Oxford University Press.

[51]LA RUE, H. 1997. Music, Literature And Etiquette: Musical Instruments And Social Identity From Castiglione To Austen cited in Ethnicity, Identity and Music: The MusicalConstruction of Place (ed) by Martin Stokes (1997), Oxford: Providence Berg Publishers.189205.

[52] LANGERS, S. 1942. Philosophy In A New key. New York: Norton.

[53]LO-BAMIJOKO. J, N. 1987. Classifications of Igbo Musical Instruments, Nigeria. African Music, vol. 6, No. 4, 19-41. Available From: http://www.jstor.org /stable /30 249789. Accessed: 7 November 2013.

[54]LEPPERT, R. 1992. Sexual Identity, Death, And The Family Piano. 19 ${ }^{\text {th }}$-Century Music, Vol. 16, No. 2, Music in Its Social Contextx (Autumn 1992), 105-128. Available From:http://www.jstor.org/stable/746261. Accessed: 13 March 2014.

[55]MATORY, J. L. 1993. Government By Seduction: History And Tropes of 'Mounting' in Oyo-Yoruba Religion, in Modernity And Its Malcontents: Power In Afrirca, edited by Jean Comaroff and John Comaroff, Chicago: University of Chicago Press. 58-85.

[56] MBITI, J. S. 1991. Introduction To African Religion. Second Edition, Nairobi, East African Traditional Publishers Ltd.

[57] METUH, E. I. 1981. God And Man In African Religion. London: Geoffrey Chapman.

[58]_ 1985. African Religions In Western Conceptual Schemes: The Problem of Interpretation. Jos: IMICO Press.

[59]__1999. God And Man In African Religion: A Case Study of The Igbo of Nigeria. ( $2^{\text {nd }}$ Edition), Enugu: SNAAP Press Ltd.

[60] MCMULLEN, D. 1987. Bureaucrats And Cosmology: The Ritual Code of T'ang China cited in Rituals of Royalty: Power and Ceremonial in Traditional Societies (ed) by David Cannadine \& Simon Price (1987), Cambridge: Cambridge University Press. 181-236.

[61] MACGAFFEY, W. 2000. Art And Spirituality cited in African Spirituality: Forms, Meanings And Expressions (ed) by Jacob K. Olupona. (2000), New York: The
Crossroad Publishing Company. 223-256.

[62] MCADAMS, D. P. 1988. Power, Intimacy, And The Life Story: Personological Inquiries Into Identity. New York \& London: The Guilford Press.

[63] MERNISSI, F. 1991.Women And Islam: An Historical And Theological Enquiry. Oxford: Blackwell Ltd.

[64] MAMA, A. 1995. Beyond The Masks: Race, Gender and Subjectivity. London and New York: Routledge.

[65] MAHMOOD, S. 2005. Politics of Piety: The Islamic Revival And The Feminist Subject. New Jersey: Princeton University Press.

[66] MURPHY, J. M. 2012. Chango Ta Veni / Chango Has Come: Spiritual Embodiment In The Afro-Cuban Ceremony, Bembe. Black Music Research Journal, Vol. 32, No. 1, 68-94. Available From: http://muse.jhu.edu/ journals/black music research_journal/v032/32.1.murphy .pdf. Accessed: 1 November 2013.

[67] MONTS, L. P. 1989. Vai Women's Roles In Music, Masking, And Ritual Performance cited inAfrican Musicology: Current Trends, Vol.1. A FestsChrift Presented to J. H. Kwabena Nketia (edited) by Jacqueline Cogdell DjeDje \& William G. Carter (1989). Atlanta, GA: Crossroads Press. 219-235.

[68] NABOFA, M. Y. 1980. Blood Symbolism In African Religion. Religious Studies, No. 21,Cambridge University Press. 389-405.

[69]_ 1994. Religious Communication: A study in African Traditional Religion, Ibadan: Daystar Press .

[70]_ 1996. Saliva Symbolisms in African Traditional Religion. ORITA Ibadan Journal of Religious Studies, Vol. XXVIII/1-2 (June \& December, 1996), 1135 .

[71] NICHOLLS, R. W. 1988. Ensemble Music of The Igede. The Black Perspectives In Music, Vol. 16, No. 2 (Autumn 1988), 191-212. Available From: http://www.jstor.org/ stable/1214808. Accessed: 28 April 2014.

[72] NNAMAH, P. A. 2002. A Centenary of A Dynasty And Ovala Celebrations From The Cradle,

a. cited in Ovala Aguleri 2002 Udo Na Njiko Aguleri Celebrating 100 years of Idigo Dynasty (1900-2000), Aguleri (ed) Paul .A. Nnamah,2002, Aguleri: Okezie Press.7-10.

[73] NANJI, A. 1994. Beginnings And Encounters: Islam in East African Contexts cited in Religion In Africa: Experience And Expression (ed) by Thomas D. Blakely, Walter E. A.Van Beek, \& Dennis L. Thomson 1994, London: Heinemann. 47-55.

[74] NEUMAN, D. M. 1980. The Life of Music In North India: The Organization of an Artistic Tradition. Detroit: Wayne State University Press.

[75] OMOREGIE, B.S 1989 . The Man Eri; University magazine, Vol. 112, the institute of African Studies, University of Ibadan, Ibadan, 41-43.

[76] ONWUEJEOGWU, M. A. 1981. An Igbo Civilization: Nri Kingdom and Hegemony. London: Ethnographica Ltd.

[77] OKAFOR, R .C. 1998. The Igbo of Nigeria cited in 
Madukasi Francis Chuks / Ozo Title: An Indigenous Institution In Traditional Religion That Upholds Patriarchy In Igbo Land South-Eastern Nigeria

Nigerian People's and Culture for Higher Education. (eds) by R. C. Okafor \& L. N. Emeka (1998) Enugu: New Generation Ventures Limited. 111-133.

[78] OJUKWU, O. C. 1998. Toward A Greater Nigeria: The Harsh Realities, Selected Speeches of Dim Emeka Odumegwu Ojukwu 1982-1998. (Compiled) by Okorie k. k \& Ugochukwu, S. S. C, U.S.A: Good Hope Enterprises, Inc.

[79] OKEKE, P. 2000. Reconfiguring Traditional Women's Right And Social Status In Contemporary Nigeria. Africa Today, Vol. 47, No. 1 (Winter, 2000), 49-63. Available From: http://www.jstor.org/stable/4187307. Accessed: 14 April 2014.

[80] OTTO .R. 1973. The Idea of the Holy, Translated by John W. Harvey, London: Oxford University Press.

[81] OKORIE, I, 1986. Where Do The Igbos Come From? Weekly Star News Paper Ltd, Enugu. Sunday, June 22: 8 9.

[82] OGUNDIPE, M. 2007. Indigenous And Contemporary Gender Concepts And Issues In Africa: Implications for Nigeria's Development. Lagos: MaIthouse Press Limited.

[83] OLUPONA, J. K. 1991. Introduction cited in African Traditional Religions: In Contemporary Society (ed) by Jacob K. Olupona. (1991), New York: Paragon House. 113.

[84] OZAH, M. A. 2006. 'The Iwali Child Queen Dance of Ogoja Nigeria'. The World of Music, Vol. 48,No.1, Music and Childhood: Creativity, Socialization, and Representation (2006), 67-82. Available From: http://www.jstor.org/stable/41699679.Accessed:27 Octob er 2014.

[85] PERANI, J. M \& WOLFF, N. H. 1999. Cloth, Dress And Art Patronage In Africa. Oxford, Oxon: Berg.

[86] PUPIL, H. 1927. The Initiate in the New World. Routledge and Paul.

[87] PALS, D. L. 2009. Introducing Religion: Readings From The Classic Theorists. New York, Oxford: Oxford University Press.

[88] REED, B \& HUFBAUER, B. 2005. 'Ancestors And Commemoration In Igbo Odo Masquerades'. RES: Anthropology and Aesthetics, No. 47 (Spring 2005), 135152. Available From: http://www.jstor.org/stable/2016 7662. Accessed: 4 August 2014.

[89]ROBERTS, A. F. 1993. Insight, or Not Seeing is Believing cited in Secrecy: African Art That Conceals And Reveals, (ed) by M. H. Nooter, New York: Museum for African Art. 65-79.

[90] RATTANSI, A. 1997. Postcolonialism and Its Contents, Economy and Society, 26: 4, 480-500. Available From: www.tandfonline.com/doi/pdf/10.1080/03085149700000 025. Accessed: February 2014.

[91] SHEPHERD, J. 1987. Music And Male Hegemony cited in R. Leppert \& S. McClary (ed), Music And Society: The Politics of Composition, Performance and Reception, Cambridge: Cambridge University Press. 151-172.

[92] STOKES, M. 1997. Introduction: Ethnicity, Identity And Music cited in Ethnicity, Identity and Music: The Musical
Construction of Place (ed) by Martin Stokes (1997) Oxford: Providence Berg Publishers.1-27.

[93] SCHNEIDER, J. 1987. 'Anthropology of Cloth' in Annual Review of Anthropology (1987), Palo Alto: Annual Review Inc. 409-448.

[94] SMITH, F. T. 1987a. Death, Ritual and Art in Africa. African Art, Vol. 21, No. 1. (Nov 1987), 28-29 + 84. Available From: http://www.jstor.org/stable/3336496. Accessed: 15 July 2014.

[95] SUGARMAN, J. C. 1989. The Nightingale And The Partridge: Singing And Gender Among Prespa Albanians. Ethnomusicology, Vol. 33, No. 2. (spring - summer, 1989), 191-215. Available From: http://www.jstor.org/ stable/924395. Accessed: 12 January 2014.

[96] THE HOLY BIBLE. King James Version (Reversed edition).

[97] UCHENDU, C. C. 1965. The Igbo of South East Nigeria. Chicago: Holt, Rinehart and Winston, Inc.

[98] VANSINA, J. 1978. The Children of Woot: A History of the Kuba Peoples. Madison: The University of Wisconsin Press.

[99] VAN ALLEN, J. 1993. Aba Riots or Igbo Women's War? Ideology, Stratification, and the Invisibility of Women cited in Gender Cross-Cultural Perspective (Edited) by Caroline B. Brettell \& Carolyn F. Sargent (1993). New Jersey: Prentice-Hall Inc. 457-473.

[100] VELEZ, M. T. 2000. Drumming for The Gods: The Life And Times of Felipe Garcia Villamil, Santero, Palero, and Abakua. Philadelphia: Temple University Press.

[101] VALJI, N; DE LA HUNT, L. A \& MOFFETT, H 2003. Where Are The Women? Gender Discrimination In Refugee Policies And Practices. 61-72. Available From: www.queensu.ca/samp/migrationresources/gender/docum ents/valji.pdf. Accessed: 14 May 2014.

[102] WOSIEN, M. G. 1992. Sacred Dance: Encounter with the Gods. Singapore: Thames and Hudson.

[103] ZELEZA, P. T. 2005. Gender Biases In African Historiography cited in African Gender Studies: A Reader (ed) by Oyeronke Oyewumi 2005, New York: Palgrave Macmillan. 207-232. 